\title{
Архетипний образ вогню в лінгвопросторі українських паремій і замовлянь
}

\author{
А. В. ВИСОЦЬКИЙ \\ Факультет української філології та літературної творчості ім. А. Малишка Національного \\ педагогічного університету ім. М. П. Драгоманова, вул. Пирогова, 9, UA-02000 Київ \\ E-mail: anatolvysotskyi@gmail.com
}

Ю. С. МАКАРЕЦЬ

Кафедра української мови Національного педагогічного університету ім. М. П. Драгоманова, проспект Маяковського, 72б, кв. 160, UA-02232 Київ

E-mail: makarets_iuliia@ukr.net

(Received: 5 September 2019; accepted: 20 November 2019)

Питання взаємодії мови і культури викликає все більше зацікавлення в науковому середовищі. Посилення глобалізаційних процесів, які ведуть до асиміляції й уніфікації культурного простору, та намагання представників національних культур зберегти свою національну ідентичність тільки сприяють посиленню цього інтересу. Відколи Е. Сепір та Б. Ворф сформулювали гіпотезу лінгвістичної відносності, стало очевидно, що людина засвоює культуру через національну мову як проміжний вимір між дійсністю і свідомістю. Розуміння ж іiі своєрідності потребує семантико-культурологічного аналізу iii елементів. Тому об'єктом дослідження лінгвістів стає не лише значення слова, а весь обсяг культурної інформації, збереженої в ньому в латентному стані. Ідеться про вивчення культурного компонента ментальних інформаційних структур, втілених у слові, що в науковій літературі позначені термінами лінгвокультурема, константа, логоепістема, міфологема, ноема и концепт, що служить ще й термінологічною парасолею для всіх попередніх понять.

Лінгвокультурологічні дослідження беруть початок у працях В. фон Гумбольдта, який стверджував, що національна культура («дух народу») втілюється у внутрішній формі мови. Ця думка знайшла продовження у гіпотезі мовної відносності, за якою людина сприймає світ через мову, а отже, мовна картина світу національно своєрідна. Попри неоднозначну оцінку вона стала каталізатором для розвитку лінгвокультурології (праці Д. Олфорда, Дж. Керолла, Д. Хаймса, Б. Серебреннікова, В. Маслової, Г. Колшанського, Р. Уайта, В. Телії, Ю. Степанова та ін.). Серед актуальних лінгвокультурологічних напрямів чільне місце посідає з'ясування ментального портрету етносу крізь призму його мови, тобто через вивчення ії глибинних етнокультурних нашарувань. У його межах досліджують «знаки етнокультури» або 
етнокультурні концепти як особливі мовно-когнітивні продукти, що постають на переплетінні етносимволіки слова та етносимволіки позначуваної ним реалії (ЖАйворонок 2006: 3). Їх ще називають поняттями-архетипами, архетипними образами або символами, концептами-архетипами, наголошуючи цим, що йдеться про глибинні психічні утворення як вияв колективного позасвідомого, родової пам'яті, що тепер існує як вроджена психічна структура (Селіванова 2011: 40).

Метою пропонованої статті $є$ семантико-культурологічне дослідження лінгвалізаторів архетипного образу вогню в українських пареміях і замовляннях. Для цього здійснений архетипний аналіз фольклорних мікротекстів і семантико-когнітивний аналіз культурного концепту вогонь та мовних засобів його репрезентації.

I мова, і культура є формами свідомості, що відображають світогляд народу. У національній мові немає того, чого б не було в культурному просторі відповідного етносу. Водночас не все, що є в культурі, представлене в мові, адже вона є тільки однією 3 кодових систем, що обслуговують культуру. Тому встановлення закріпленого в ній культурного змісту дозволяє з'ясувати ієрархію культурних цінностей етносу та особливості інтерпретації ним явищ навколишнього світу. Паремії як мовні вияви стереотипних для певного етносу асоціацій і оцінок, замовляння як мовні формули, що втілюють міфологічну віру в магію слова, і тому містять тільки найсильніші з погляду мовців знаки етнокультури, як предмет лінгвокультурологічного аналізу дають змогу виявити найбільш стійкі та значимі культурні семи архетипних образів.

Культ вогню - невід'ємний елемент давніх культур, адже саме світло вогню розсіяло нічну темряву, у якій на первісну людину чигало чимало небезпек і яка вселяла страх. На різних етапах розвитку сліди вогнепоклонства, містичного шанування земного вогню як втілення вогню небесного (Сонця) та як необхідної умови виживання простежують і у колишніх кочових народів, і в осілих землеробів. Із язичницьких культів перейшов він і в християнство. Така його стійкість свідчить про належність до сфери глибинних людських уявлень. Звідси, наприклад, старозавітні образи вогненного стовпа як божественного явлення, що вказував шлях уночі, та неопалимої купини, у вигляді якої Мойсеєві явився Господь, а також численні біблійні мікроконтексти, у яких ідеться про втілення у вогні Божої сили та про вогонь як божественне покарання. Це продовження первинних сакральних язичницьких уявлень, що перетворилися на глибинні ментальні одиниці.

Культ вогню відігравав важливу роль у житті слов'ян. Знання, досвід, вірування, пов'язані із вогнем, широко репрезентовані й сьогодні у мовній картині світу слов'янських народів, зокрема українців. На мовному рівні про його вагому роль свідчить, наприклад, розвиненість дериваційних зв'язків та розгалуженість в українській мові словотвірного гнізда 3 вершиною вогонь. У «Словарі української мови» Б. Грінченка зафіксовано: вогник (огник), вогничок, вогнище (огнище), вогнюватий ('палкий'), вогнюватий, вогняний, вогоник (Грінченко 1: 246). Пор. у «Словнику української мови» в 20 томах: 
ім. вогниво, вогник, вогнисько, вогничок, вогнище; дієсл. вогневіти, вогніти; прикм. вогнищевий, вогнястий, вогняний, вогнищний, вогнистий, вогненний, вогневий (СУМ 3: 713-716). Від лексеми вогонь похідними є назви хвороб (вогневичя), рослин (вогничок), зокрема міфічних (вогнецвіт), комах (вогнів$\kappa a)$, а також діалектні назви огнина (іскра), огниця (комаха), огняк (птах), огняник, огнянецьь (дух вогню), вогняниця (гриб) (ЕСУМ 1: 413). Те саме значення реалізують менш вживані, стилістично марковані лексеми полум'я, полумінь, жевриво, багаття, ватра (КАРАВАНсьКий 2000: 58). 3 діалектною лексемою ватра пов'язані похідні ватерь (житло гуцула), ваторник (частина житла гуцула, де сплять і варять страву), ватрак (кухонне вогнище надворі), ватралка (кочерга), ватралька, ватран, ватрач, ватрачка, ватрисько (місце, де була ватра), ватрище (вогнище), ватроль (дерев'яний рогач; йолоп), заватра (другий вогонь) (ЕСУМ 1: 339-340).

Образ вогню лежить в основі чималої кількості фразеологічних одиниць української мови, які вербалізують досвід у поводженні $з$ вогнем та основні уявлення про нього: пустити з вогнем, боятися як вогню, пішло з вогнем, гратися з вогнем (вогонь - руйнівна сила і джерело небезпеки); як вогню вхопив, горить у руках, дівчина як вогонь (про швидкість); гарячий як вогонь, дутися як лопух (икіра) на вогні, летіти як метелик на вогонь (про рису вдачі людини); сидить як на вогні, аж вогнем сипле, без вогника, працювати з запалом, вогнем дихати, вогнем горіти (про стан людини) тощо (ФСУМ 1: 140141). Із давніми уявленнями про вогонь як джерело життя, божественну силу та центр, навколо якого організований світ людського помешкання, пов'язані відповідно вислови живий вогонь, святий вогонь, домашнє вогнище та ін.

Та чи не найвиразніше тезу О. Потебні про те, що мова розвинулася 3 міфів, утворених за допомогою слова, і що чи не за кожним словом стоїть чуттєвий образ, що сягає корінням міфологічних уявлень (ПотЕьня 1989: 270-274), доводить аналіз лексичних одиниць на матеріалі фольклорних текстів, зокрема паремій та примовлянь. Важливою передумовою культурно-семантичного аналізу образу, реалізованого в слові, є детальне з'ясування місця й ролі позначуваної реалії в житті представників етносу.

Українці вважали вогонь межею між світами живих і померлих. Серед слов'янських племен за язичницьких часів був звичай спалювати небіжчиків, про що збереглися свідчення арабського мандрівника Ібн-Фадлана від 922 р., який описав похорон-спалення руського купця. І. Огієнко, аналізуючи культурно-релігійне підгрунтя цього обряду, зазначав: «Коли мерця палили, то вірили, що душа померлого з димом відразу дістанеться на Небо до Раю, бо вогонь легко відділює душу від тіла, і душа спокійно керується на Небо...» (ІлАРІон 1994: 244). Із цим віруванням пов'язаний і обряд запалювання вогню біля хати під час похорону.

Вогонь слов'янина - це втілення божественної сили на землі. Обожнення його пов'язане $з$ тим, що вогонь, з одного боку, був необхідний для життя, оскільки зігрівав у холод, освітлював темряву, служив для приготування їжі. Разом із тим він міг і спалити ціле помешкання чи й поселення. Тому вогнище 
шанували. Звідси повір'я, що у вогонь не можна плювати, та обряд принесення жертви домашньому вогнищу (овину), щоб його задобрити. «Домове вогнище (очаг), на якому горів невгасимий вогонь, здавна був головною Святинею дому, - він беріг щастя дому і всіх членів родини. Домове родинне вогнище було в нас першим жертівником, а голова родини - першим жерцем» (ІЛАРІОн 1994: 124). Щоб стримати руйнівну вогняну стихію, витворили систему обрядів і ритуалів, пов'язаних із жертвоприношеннями. Жертвами овину були півень (через червоний гребінь його вважали вогняним птахом), зерно й вода, які ставили в піч після випікання хлібу.

Вогонь - символ верховного бога слов'янського пантеону Перуна. Біля ідола громовержця мав палати живий вогонь, добутий тертям у чітко визначений час доби (зазвичай до сходу сонця). Від нього запалювали вогнище на Івана Купала та на свято Коляди (пізніше стало традицією цим вогнем розпалювати в печі 12 полін, щоб приготувати ритуальні різдвяні страви). У деяких регіонах його зберігали протягом усього року, не даючи згаснути.

Як втілення божественного начала, вогонь наділяли очисною силою. Тому через вогнище на Івана Купала (купайлицю), на Великдень і Різдво перестрибували й переводили через нього худобу. Обкурювали ним і хати. Iз цим уявленням пов'язаний і звичай присмалювати молоду (або присмалювати свекруху): не перейшовши через вогонь, «не обсмалена» наречена не могла стати дружиною, бо цим перевіряли іï доброчесність.

Як втілення божественної сили на землі вогонь у вигляді розкладеного багаття чи свічки був важливим «учасником» всіх ритуалів, але означеним богом так і не став, хоч подекуди в пам'ятках і називали його вогнем-Сварожичем, а в списку XIV ст. сказано: «I огневі Сварожиці моляться», «моляться под овином огневи» (Слово 1914: 370). Підтверджує це й аналіз фольклорних мікротекстів. Якщо культурологічне тло формування семантики етнознака вогню засвідчує уявлення про втілення у ньому божественного начала, то в пареміях пов'язана із божественною природою очисна функція не знаходить широкого втілення. Реалізується вона частково тільки в замовляннях від хвороб. Ці тексти апелюють швидше до нищівної здатності вогню, ніж до очищувальною. Хоч вогонь, як і вода, у культурі - це амбівалентна стихія, яка і очищує, і карає, однак у мовній картині світу українців цей етнознак маркований перш за все негативно - вогонь має вилікувати, але не зціливши, а налякавши хворобу:

Ви, сухоти сухотищі, чи ви подумані, чи ви погадані, чи ви помислені, чи ви стрічні, чи ви чоловічі, чи ви жіночі, чи ви парубочі, чи ви дівчачі, чи ви дитячі, чи ви які на світі! Ви, сухоти сухущі, болющі, палющі, розійдіться від младенця Івана, та nidimb собi за огнем, за полум'ям, як дим 3 димаря розлітається і розкочується, то так і ви, сухоти, сухотищі, розійдіться, розкотіться за огнем, за димом, за вітром, за полум'ям, тихенько, легенько, маковим дробовим хмелем, і дайте спати, спочивати младенцеві Івану!

Як зазначає А. Новикова, у таких текстах «перед нами гомеопатична магія: подібне (жар хвороб) лікується подібним (вогнем)» (НовиковА 1993: 256). 
У наведеному контексті вислів піти за огнем, за полум'ям синонімічний із вживаною в українській мові фразеологічною одиницею піти (спливти) за водою ('минути, зникнути'), хоча вогонь і вода - антонімічні поняття, протилежні стихії.

Усвідомлення протилежності і водночас амбівалентності води й вогню фіксують паремії. При цьому вогонь все ж має негативний ухил, а вода - позитивний:

Вода з вогнем не товаримі.

Трудна згода, де вогонь і вода.

Не погодии огонь з водою.

Огонь та вода - то добро та біда.

Огонь гіриий ворог як вода. Бо вода одному візьме, а другому дасть, а огонь нічого не лишить.

Огонь гіриий як злодій, бо злодій украде і другому дасть, а вогонь ні.

Приказки і прислів'я, побудовані на образах вогню і води, часом можуть не містити самих їх вербалізаторів, а втілювати типові вогняні і водні сценаpii, наприклад, горіти й тонути:

Що має горіти, то не потоне.

Мокрого поліна вогонь не лиже.

Якщо вогонь і вода в пареміях здебільшого протиставлені, то в замовляннях трапляються поєднання цих стихій. Звідси, наприклад, оксиморонний образ вогняної ріки:

Калиновим мостом ішло три сестри: Калина, Малина і Шипшина. Не вміли вони ні шити, ні прясти, тільки вміли сікти-рубати, ріки пропускати: одна ріка водяная, друга ріка огняная, третя ріка кров'яная. Водяною огонь заливати, кров'яною кров унімати.

Лінгвалізація типових вогняних сценаріїв пов'язана 3 вживанням відповідних предикатів, зокрема пекти, палити, потухати, потушити, в'ялити (трави), сушити (землю). Наприклад:

Огні, ангели і архангели: і палаєш, і потухаєш, потуши нарожденному, хрещеному, молитвенному рабу Божому Івану бех і бешиху, і пожарну, і пристрітну.

«Добривечір тобі, огненний бугало!» - «Здорова, хрещена, нарожденна, молитвяна раба Божая дівчино!» - «Куди ти летиш?» - «Полечу ліса палить, а землі сушить, а трави в’ялить». - «Не лети ж ти, огненний бугало, ліса палить, землі сушить, а трави в'ялить! Полети ж ти, огненний бугало, до козака у двір. Де ти його спобіжиш, де ти його заскочиш: чи в лузі, чи в дорозі, чи в наїдках, чи у вечері, чи у постелі, - учепися ти йому за серце, затоми ти його, запали ти його: щоб він трясся і трепетався душею і тілом за мною, нарожденною, хрещеною, молитвяною дівчиною Марією, щоб він мене не запив, не заїв і з іншими не загуляв, усе мене на помислах мав. Тягніть до мене, нарожденної, хрещеної і молитвяної дівчини Марії нарожденного, хрещеного і молитвяного козака Івана!» 
У любовних замовляннях частим $€$ порівняння серця, у якому зароджується кохання, з воском, який плавиться:

В лісі росло дерево, убирало си в кору, в краки, в лист, у цвіт. Стяли його. Як не має воно тепер сили рости, цвісти, так аби не мали сили уроки панські, циганські, діточі, жидівські, парубоцькі, дівоцькі, жаб’ячі і гадячі. Аби так щезли, пропали, як пропадає сіль від води і віск від огню!

Щоб тебе за мною так пекло, як пече вогонь той віск! Щоб твоє серце за мною так топилось, як топиться той віск, і щоб ти мене тогді покинув, коли найдеш той віск!

У любовних замовляннях трапляється номінатема огненний бугало, що пече і палить, викликаючи любовну гарячку. Фіксує іiі i «Словарь української мови» Б. Грінченка із зазначенням, що назва трапляється в замовляннях, але без тлумачення (Грінченко 1: 105). Однозначного пояснення семантики номінатеми немає. Припускають, що це або блискавка, яка розсікає небо, чи метеорит (Аліксійчук 2013: 269), або вогненний змій, перелесник (ЖАйворонок 2006: 248-249).

Згідно з давніми повір'ями ця міфічна істота здатна вселити «вогонь кохання» в серце чоловіка, а жінкам з'являється у вигляді молодого парубка, спокушаючи на перелюб, може пити їхню кров і довести до смерті (ЖАйвоРонок 2006: 248-249, ВижЕнко). Номінатема засвідчує зближення культу вогню із культом змія, однак у пареміологічних контекстах це не засвідчено.

Наведені контексти дають підстави тлумачити вогонь як символ сильного почуття або переживання, тож ця стихія проникає й в уявлення про внутрішній світ людини. Тут вогонь також постає ворожою силою, яка пече, $n a$ лить і від якою людина пропадає. Часто у подібних замовляннях саме словолінгвалізатор не вжите, але його імпліцитна присутність очевидна, оскільки ословлений сценарій, у якому образ типово задіяний. При цьому відповідні предикати у семантичній структурі містять сему 'вогонь': пекти - 'готувати на вогні, на жару', палити - 'знищувати вогнем' тощо.

Перенесення 'вогонь - внутрішній світ людини' ширше реалізоване в прислів'ях і приказках, де образ вогню використаний для окреслення характеру, поведінки або вчинку:

Робить як мерзле горить.

Бурлак сам горить, як свічка: як до роботи, як до охоти.

То огонь не чоловік.

Той би й на терновім огні не горів.

Сусідська річ позичати вогню.

Прийшов як огню урвати (позичити).

У пареміях позитивна семантика вогню реалізована тільки зрідка: як сили, яка захищає чи відганяє лихо. Втілюється вона через прийом паралелізму:

Креши вогню, жени біду. 
Про святий вогонь у аналізованих фольклорних мікротекстах $є$ тільки поодинокі згадки:

Огонь святий мститься, як його не шануєш.

Приказка апелює до міфологічного уявлення про охорону силу вогню, пов'язаного з давнім страхом людини перед невідомістю, яка чаїться в темряві, та здатністю вогню цю темряву розсіяти (те саме у замовлянні Вогонь та зола, ізбав мене від зла).

Про давне шанування вогню свідчить приказка Вогонь - цар, а вода цариия. Паремії На злодієві й шапка горить, Той кричить, у кого шапка горить, Правда в воді не тоне, а в вогні не горить пов'язані з уявленням про те, що вогнем можна виявити правду. Робили це через спалення або проведенням крізь полум'я: якщо людина не згорить / не загориться, то вона невинна. Звідси й тема вогню як випробування, реалізована у фразеологічних одиницях хоч ріжте, вогнем печіть, в вогонь за ним пішов би, разом $і$ у вогонь, $і$ в воду та пареміях Міџну дружбу і вогонь не спопелить, Пробуй золото вогнем, а дружбу грішми та Тебе аби на терновім огні пік, то би сі від тебе правди не довідав тощо.

Поряд із семантикою випробування вогонь реалізує і значення біди або загрози:

Тікав від диму, та впав у вогонь.

Вогонь - біда і вода - біда, а без вогню і без води ще більша біда.

Вогонь - добрий слуга, але поганий хазяйн.

Негативну маркованість вогню засвідчує розмаїття побудованих на цьому символі і його типових сценаріях приказок-прокльонів, наприклад:

Щоб ти згорів без вогню!

Щоб ти зітлів!

Бодай тебе сніг спалив!

Сонще би тебе спалило!

Бодай тебе грець спалив у діжі!

Пареміологічні мікроконтексти виявляють в образі вогню й значення горя, печалі, лиха, що втілене зокрема через підпорядкований вогневі образ пожежі (в українській пареміології вона стається у хаті або в церкві):

Церква горить, а люди руки гріють.

Свисти, попе, иерква горить.

Не моє горить, не буду гасити.

Коли хата горить, тоді люди не сваряться.

Подібні значення засвідчені в тих контекстах, де у лінгвалізованому вогняному сценарії номінатема вогонь заміщена назвою відповідного почуття чи стану: 
Горе слізьми не погасиш.

Радість красить, а печаль палить.

Часто образ вогню у приказках постає ілюстрацією причиново-наслідкових зв'язків між явищами:

Нема диму без вогню.

Із малої іскри великий вогонь буває.

Полум'я не без вогню.

Гаси вогонь, поки не розгорівся.

Вогонь вогнем не загасии.

Носієм ідеї вогню є і слово-поняття свічка (Кононенко 2001: 151), що стала неодмінним символом родинних і церковних обрядів. «Стоїть вона на столі на Різдво, викопчують нею хрести на покутті на Водохреще, запалену свічку дають у руки нареченим і покійнику. Коли вмирає людина, конче мусить горіти свічка в руках іiі, і то свічка громнична. У ритуальних обрядах свічка грала важливу ролю ще до Християнства; вогонь був символом і плідности, тому свічок уживається на Весіллі... Умираючому в нас дають свічку в руки, щоб освічував собі дорогу на той світ» (ІлАРІОН 1994: 328). Символ свічки реалізує семантику віри й розуму. У релігійній традиції він стає емблемою церкви й духовного світла. Пареміологічні одиниці здебільшого засвідчують вживання його у поєднанні зі словом-поняттям чорт. Подібні мікроконтексти можна пояснити здатністю людей підхоплювати й узагальнювати парадоксальні прояви буденного життя, які й утілені у приказках:

I чортові треба часом свічку запалити.

Палить свічку $і$ богу $і$ чортові.

Вислів запалити свічку реалізовує значення 'згадати', 'послужити'. Як символ розуму постає свічка у пареміях:

Голова без розуму, як ліхтарня без свічки.

Кому видно, тому й свічки не треба.

Земний вогонь уявлявся втіленням вогню небесного, а отже, був продовженням культу сонця і пов'язаний з блискавкою. Живий вогонь добували тертям, бо вважали, що саме від тертя, що виникає при обертанні сонячного колеса, розгоряється і сонце. Небесним джерелом вогню була й блискавка: «Блискавка - це небесний вогонь, що його посилає бог чи то на кару людям, чи на відігнання злих сил, тому не можна гасити пожару від неї, хіба тільки... молоком» (ІлАРІон 1994: 31). А отже, семантика сонця та блискавки також перетинається із символічним значенням вогню, хоча аналізованими пареміологічними мікроконтекстами це не засвідчено.

Як відзначає В. Жайворонок, «...символізації зазнає звичайно значення слова через узагальнення його внутрішнього образу, тому символи завжди 
мають щось спільне з тим, що вони символізують» (ЖАЙворОнок 2007: 88). О. Потебня виділив кілька когнітивних основ символізації: порівняння та зіставлення, протиставлення та виявлення причинових відношень (ПотЕБня 1985: 206-210). Аналіз зібраного пареміологічного матеріалу засвідчує, що глибинною основою символізації внутрішнього образу слова вогонь $є$ порівняння та асоціативне уподібнення.

3 дурнем каші і не звариш: або пшоно не вкипить, або вогонь не горить.

Стережися тих вечорниць, як мати тебе від вогню стерегла.

Гуляють, аж підковами огню крешуть.

Від огня, води і злої жони - боже борони!

3 золотом, як з вогнем: $і$ тепло з ним і небезпечно.

Закон не огонь, водою не заллєи.

Чимало паремій побудовані так, що лінгвалізований лише образ, iз яким відбулося порівняння, натомість порівнюване присутнє тільки імпліцитно:

Без вогню варить.

Де дим, там і вогонь.

Від огню біжу, а в воду скачу.

Не сховаєш огню в соломі.

Лінгвальний простір паремій і замовлянь як конденсованого вияву досвіду й розуміння причиново-наслідкових зв'язків між явищами засвідчує, що символ вогню - один 3 центральних елементів колективної культурної пам'яті, яка зберігає уявлення про нього як амбівалентну стихію, наділену руйнівною і водночас життєдайною силою.

Аналізовані мікроконтексти вербалізують не весь культурологічний зміст аналізованого архетипного символу, у них не зафіксовані випадки його обожнення як найвищого вияву культу вогню. Натомість паремії, збережені в українському мовно-культурному просторі, лінгвалізують стереотипну асоціативну схожість вогню та нещастя чи випробувань, рідше - вогню та сильних руйнівних почуттів чи неспокійного характеру.

Семантика випробування чи очищення вогнем значно частіше, ніж у приказках, реалізується у фразеологічних одиницях української мови. У замовляннях вогонь - це частина гомеопатичної магії, стихія, який може відлякати хворобу або спалити їі, тобто вилікувати подібне подібним. Крім того, символ вогню є важливим елементом любовної магії, побудованої на схожості природного явища і почуття людини.

Пізнавальною основою такої символізації є механізми асоціативного засвоєння та порівняння, за допомогою яких первісні люди пізнавали та структурували світ. Людському мисленню властива образність, потреба відштовхуватися від знайомого образу під час пізнання нового - одна з визначальних його особливостей. Звідси й метафоричні трактування та семи, що поступово сформували широке значеннєве поле архетипного символу вогню. 


\section{Література}

АлІксійчук 2013 = Алाксійчук О. С. Астральна символіка українських народних пісень у хорових обробках М. Д. Леонтовича. Педагогічна освіта: теорія і практика 13 (2013): 265-270.

ВиЖЕНКО = ВиЖЕНКо О. Украӥна кохання. http://dotyk.in.ua/ualove9.htm.

ВИшНЕВСьКА-КОМЕНДАНТ 2011 = ВИшНЕВСьКА Г., КОМЕНДАНТ С. ВоГонь Як природне явище і багатоликий символ. Рідний край 2011/2: 68-73.

ВОРОПАЙ 1958 = ВоРОПАЙ О. Звичаї нашого народу. Етнографічний нарис. Мюнхен, 1958.

ГРІнЧЕНКО = ГРІнЧенКо Б. Словарь украӥнської мови. Т. 1-4. Київ, 1907-1909.

ЕСУМ = Етимологічний словник украӥнської мови. Т. 1. Київ, 1982.

ЖАЙВОРОНОК 2006 = ЖАЙВОРОНОК В. Знаки украӥнської етнокультури. Словник-довідник. Київ, 2006.

ЖАЙВОРОНОК 2007 = ЖАЙВОРОНОк В. Украӥнська етнолінгвістика. Київ, 2007.

ІлАРІОН 1994 = ІлАРІОН: Дохристиянські вірування украӥнського народу. Київ, 1994.

КАРАВАНСьКИЙ 2000 = КАРАВАНСьКИЙ С. Практичний словник синонімів украӥнської мови. Київ, 2000.

КОНОНЕНКО 2001 = КоНОНЕНКо В. Рідне слово. Київ, 2001.

НовиковА 1993 = НовиковА М. Коментар. В кн.: МоскАЛЕНКо М. Н. Украӥнські замовляння. Київ, 1993. 199-306.

Номис 1864 = Номис М. Українські приказки, прислів'я, і таке інше. Санкт-Петербург, 1864.

ПотЕБНЯ 1985 = ПотеБНя О. Естетика і поетика слова. Київ, 1985.

ПоТЕБНЯ 1989 = ПотЕБНЯ А. Слово и миф. Москва, 1989.

ПРУСП = Практичний російсько-український словник приказок. Київ, 2009.

СЕЛІВАНОВА 2011 = СЕЛІвАНОВА О. Лінгвістична енциклопедія. Полтава, 2011.

Слово 1914 = Слово нъкоего хрістолюбца и рєвнитєлА по правои вђрђ. В кн.: Аничковъ Е. В. Язычество и Древняя Русь. Санкт-Петербург, 1914. 369-373.

СУМ = Словник украӥнської мови. Т. 3. Київ, 2012.

УЖЧЕНКО 2005 = УЖЧЕНКо В. Д., УЖЧЕНКО Д. В. Фразеологія сучасної української мови. Луганська, 2005.

ФСУМ = Фразеологічний словник української мови. Т. 1-2. Київ, 1999.

ШУМАДА 1985 = ШУМАДА Н. С. Народ скаже як зав'яже. Украӥнські народні прислів'я, приказки, загадки, скоромовки. Київ, 1985.

\section{Anatoli Vasylovych Vysotskyi, IUliIa SerhitVna MaKarets \\ National Pedagogical Dragomanov University (Kyiv)}

\section{The Archetypal Image of Fire in Language Space of Ukrainian Paroemias and Verbal Folk Magic}

This paper deals with the linguocultural analysis of the semantic content of the archetypal symbol of fire. It is one of the deep mental formations, a manifestation of the collective subconscious, the generic memory, so its shades of meaning are best expressed in microcontexts that retain stereotypical associations and evaluations for a certain ethnos as well as in the linguistic formulas of word magic, which is inherent in primitive consciousness. 
Such are the texts of paroemias and verbal folk magic, on the basis of which the research is conducted. Although ancient Ukrainians knew the cult of fire and thought that it had a divine power, the analyzed linguistic microcontexts did not show the lingualization of deification of fire. Fire appears as an ambivalent element, destructive but simultaneously life-giving, with the predominance of negative marking. Fire mostly is opposed to water, which is also an ambivalent element but with a positive beginning. Ukrainian paroemiology predominantly testifies stereotypical associative similarity of fire and misfortune or trial, more rarely - of fire and strong destructive feelings or restless nature. Analyzed Ukrainian proverbs do not contain Christian understanding of fire, only ancient, pagan ideas about it. In verbal magic, fire is a part of homeopathic magic, an element that can scare off a disease or burn it, that is, cure the like with the like. More rarely, fire is a part of love magic based on similarity of natural fire and the fire of feelings. Of particular interest in this context is the image of 'fiery bugalo' that burns, causing a love fever. This image is connected with the cult of the seductive serpent, a mythical creature that can install a 'fire of love' in the heart of a man, and appears to women as tempting young man.

The mediator of the idea of fire is also the word-concept 'candle'. This symbol implements the semantics of faith and mind. In religious tradition, it becomes the emblem of the church and the spiritual light. Paroemiological units mostly attest to its use in combination with the word-concept 'devil'. Such microcontexts can be explained by the ability of people to pick up and summarize the paradoxical manifestations of everyday life. Ethnographic studies suggest that the semantics of sun and lightning also intersect with the symbolic meaning of fire, although this is not confirmed by the analyzed paroemological microcontexts.

The cognitive basis of such symbolization are the mechanisms of associative assimilation and comparison through which the primeval people cognized and structured the world. The symbol of fire becoming the basis of paroemological and magical microcontexts is sometimes not lingualized directly and manifests itself through typical scenarios with predicates to smoke, to burn, to scorch, etc.

Keywords: ethnolinguistics, archetypal image, lingualization, verbalizer, archetype, fire, verbal folk magic, paroemia, proverb 